\title{
Editorial: Action Research
}

\author{
Chris McPhee, Editor-in-Chief \\ Magnus Hoppe and Erik Lindhult, Guest Editors
}

\section{From the Editor-in-Chief}

Welcome to the April 2019 issue of the Technology Innovation Management Review. This is the first of two issues on the theme of Action Research, and it is my pleasure to introduce our guest editors: Magnus Hoppe and Erik Lindhult from Mälardalen University in Sweden. Magnus and Erik are also both Board Member of the Swedish Interactive Research Association (SIRA), and Erik is a Board Member of the Swedish Participative Action Research Community (SPARC).

For future issues, we are accepting general submissions of articles on technology entrepreneurship, innovation management, and other topics relevant to launching and growing technology companies and solving practical problems in emerging domains. Please contact us (timreview.ca/contact) with potential article topics and submissions, and proposals for future special issues.

\section{Chris McPhee \\ Editor-in-Chief}

\section{From the Guest Editors}

Researching together across different borders, especially in innovation, is becoming more common. Through this approach, a multitude of perspectives and knowledge enhance the chances of success. Indeed, there is much to gain from bringing together existing disciplinary fields and fertilizing thinking by purposefully encouraging people with diverging ideas and mindsets to work together, both for practical purposes and research purposes. But, for this work to proceed and succeed, borders must be broken down or overcome - including the artificial border between the researcher and the researched. Such efforts to break down borders belong not just to one tradition but many, and they are undertaken with different names, designs, and preferred outcomes (Reason \& Bradbury, 2008), where one label is "action research". This diversity of emerging traditions that seek to combine practical and research knowledge development intrigues us, but it also means that relevant insights are scattered and new borders are created.

Through this special issue and the one that follows it, we sought to publish articles that will help us better understand these mutual processes through an exploration of new and contemporary accounts of "action research" and its close relative "participatory action research", which stresses the mutuality of the approach. Action research can in turn be divided into a critical and a pragmatic tradition, according to Johansson and Lindhult (2008) where they "... associate the pragmatic orientation with a focus on praxis and practical knowledge development, cooperation between all concerned parties, and the need for finding and constructing a common ground between them as a platform for action".

Tracing the origin of action research, a pragmatic thread leads back to the United States, where Kurt Lewin (1946), the main instigator of the concept (Adelman, 1993), showed through field experiments that the participation of people in organizational and social development could overcome resistance to change. A critical thread leads us to Latin America and the quest to bring about social change through reflection/learning/knowledge creation and the engagement by scholars in the everyday life of disempowered groups (Fals-Borda \& Rahman, 1991; Freire, 1985). It is also inspired by neomarxist and 


\title{
Editorial: Action Research
}

\author{
Chris McPhee, Magnus Hoppe, and Erik Lindhult
}

critical theory (Kemmis et al., 2015) in enabling people to be critical and act in relation to social injustice.

A pragmatic and Lewinian tradition, aimed at creating dialogue for mutual benefit and to support participatory development, has been active in industrial, social, and organizational reform and development, predominantly aimed at solving more technical problems in society. Among these problems are those of innovation, where it also has become fashionable for companies to open up development processes to customers, external experts, and others. Creating knowledge together, in and through action across borders, is becoming a new norm for many companies and other organizations. Open innovation, a term coined by Henry Chesbrough (2003), can thus be said to rest on ideas connected to action research, where both open innovation and action research appear as modern in the sense of being more concerned with relevance and results than discriminating between certain established domains of practice.

More specifically, the introduction of action research in innovation processes is vague. The most cited work is by Robert Kaplan (1998), who stated that he used "innovation action research" when constructing the Business Score Card framework together with David Norton. By this, he means an iterative development process between theory and practice, a method he also advocates strongly in order to increase research relevance.

As the references to both Chesbrough and Kaplan indicate, ideas related to participative and action research are present in today's more popular practices. As they concern problems that are directly relevant to society today, it comes as no surprise. They do not discourage anyone from building theory, creating knowledge, or interpreting patterns. In this sense, action research approaches are also a threat to existing power structures in academia. Current borders that uphold disciplines, careers, and publication practices are threatened, as explored by Hoppe later in this issue by asking whether this challenging position makes make it harder to get action research articles accepted in more traditional journals.

In putting together two special issues on action research, our aim was to express this discussion in an accessible manner such that academics, industry, and the public sector can adopt the frameworks, models, and ideas presented by the authors. In this first issue, we present six articles in which the authors share their in- sights of breaking down or working across the borders that characterize the field of action research.

In the first article, Katharina Ruckstuhl, Rafaela C. C. Rabello, and Sally Davenport follow an additive manufacturing project team "in real time" as it navigates "fuzzy areas" to integrate knowledge to produce commercializable science innovation in one of New Zealand's National Science Challenges (NSC): Science for Technological Innovation - Kia Kotahi Mai: Te Ao Pūtaiao me Te Ao Hangarau (SfTI). Through action research as praxis and as critical orientation, key mechanisms are identified in interdisciplinary and transdisciplinary research for commercialization, particularly in the context of New Zealand's indigenous Māori people.

In the second article, Armando Machevo Ussivane, Chairman of a Mozambique Government agency, together with Paul Ellwood from the University of Liverpool, adopt a participatory action research methodology to investigate how the co-inquiry of action research can be used for mutual problem solving. The empirical data comes from a technology transfer project for rice production technology from China to Mozambique, which displayed a need to improve the coordination of autonomous innovation activities. Involved stakeholders identified four categories of organizational boundary problems that helped the different actors to reach an understanding of each other's positions.

Then, Malin Lindberg, from Luleå University of Technology and Daniel Hallencreutz and Anna Tengqvist, senior consultants for WSP in Sweden, use a participatory case study to distinguish the relationship and potential synergies between European Union research and innovation policies and participatory action research approaches. Through the research process, a model for social innovation support was jointly created, emphasizing the transformative goals of social innovation, where the authors conclude that European Union policies for stakeholder involvement work well with an action research approach.

Next, Anna Sannö and Anna Ericson Öberg from Volvo Construction Equipment, together with Erik FloresGarcia from Mälardalen university and Mats Jackson from Jönköping University, use six different research projects to explore how both practical and theoretical impact can be enhanced by considering certain key factors in a collaborative research process. The authors especially mention that effective management of the phases of problem formulation, methodology, and results is important for successful collaboration and, thereby, impact. 


\section{Editorial: Action Research}

\section{Chris McPhee, Magnus Hoppe, and Erik Lindhult}

Matthias Guertler and Nathalie Sick from the University of Technology Sydney (UTS), Australia, and Anton Kriz from the Australian National University (ANU) conduct a discipline-spanning, bibliographic overview of the landscape of action research and its implications for technology and innovation management (TIM). They argue that the iterative and learning character of action research is suitable for exploring complex socio-technical problems prevalent in TIM, but they find that the use of action research in TIM research is surprisingly limited but mounting. Their study shows, strikingly, "that the most productive journals (total number of articles) publishing action research are discipline-spanning and action research specific, while the most influential journals as well as articles (impact factor, citations per article) are published in discipline-specific journals". The review indicates that there is potential for enhanced use of action research in TIM and in TIM journals, and the authors use qualitative analysis to synthesize the benefits and challenges in using this type of approach.

In the final article, Magnus Hoppe from Mälardalen University in Sweden explores publication patterns for participatory and action research in innovation journals with the aim to provide advice in choosing outlets. It is done through a bibliographical review of all 33 innovation journals listed in the 2018 Academic Journal Guide, complemented with a case study of this journal, the TIM Review. The study finds positive signs that action research is moving from the margin to the mainstream, where the movement towards openness in innovation and in publication practices are supportive trends. The results are challenging the not uncommon view, also expressed in the call to this special issue, that it is more difficult to publish action research in high-ranked journals. Hoppe finds that publications are spread out over different journals but that "we lack a clear answer to the question of what is the best outlet". He invites us to reflect upon what kind of impact we want to have and to choose outlets accordingly.
The articles may diverge in many ways, but they all emphasize that action research "should not be based on the interest of only one of the stakeholders", as Sannö and colleagues phrase it in their article. By using action research, different stakeholders will be forced to at least listen to what other parties have to say. However, as described in the articles in this special issue, they will also realize that the best results come from mutual definitions of key problems as well as working together across borders in order to solve identified problems.

In closing, we emphasize that doing research together across borders require researchers and collaborators to engage in often complex issues in bridging borders and dealing with boundaries in order to integrate forms of knowing, various disciplines, and knowledge interests in producing both scientific and actionable knowledge, and both theory and transformation. This shows both the scientific and practical potential of action research in bridging and integrating action, problem solving, and transformation with research and scientific activity. The articles in this first special issue deal with and contribute to this endeavour in different ways, and we look forward to the second special issue, which will further show how action research approaches in various ways can support and enable the bridging across borders.

\section{Magnus Hoppe and Erik Lindhult Guest Editors}




\section{Editorial: Action Research}

\section{Chris McPhee, Magnus Hoppe, and Erik Lindhult}

\section{About the Editors}

Chris McPhee is Editor-in-Chief of the Technology Innovation Management Review. Chris holds an MASc degree in Technology Innovation Management from Carleton University in Ottawa, Canada, and BScH and MSc degrees in Biology from Queen's University in Kingston, Canada. He has 20 years of management, design, and content-development experience in Canada and Scotland, primarily in the science, health, and education sectors. As an advisor and editor, he helps entrepreneurs, executives, and researchers develop and express their ideas.

Magnus Hoppe is an Associate Professor at the School of Economics, Society and Engineering at Mälardalen University, Sweden. At the university, he is member of the Faculty Board and leads processes for collaborative research in sustainable development. Magnus holds a $\mathrm{PhD}$ in Business Administration from Åbo Akademi University in Finland, where he presented his thesis on organized intelligence work in modern organizations. His current research concerns both private and public organizations and spans intelligence, entrepreneurship, and innovation. A special research interest lies in questioning dominating perspectives that bind our understanding of specific topics, and he now works to establish new ways of talking and thinking about innovation. His aim is to help organizations build new insights that will enhance their ideation processes and strategy building and, thereby, improve their innovative capabilities.

Erik Lindhult (Ph.D.) is a Senior Lecturer in Innovation Management and Entrepreneurship at Mälardalen University in Sweden. He received his doctoral degree in Industrial Management from the Royal Institute of Technology in Stockholm, in the area of Scandinavian dialogue democratic approach to innovation and action research. His main area of research is participatory, collaborative, and democratic innovation and change management, as well as entrepreneurship for a sustainable development of society. His research interests also involve collaborative research methodologies, including action research and interactive research. He has been involved in a wide range of collaborative $R \& D$ projects in the private, public, and cooperative sectors, in areas such as organizational development, incubator and science park development, service innovation, societal entrepreneurship, sustainable innovation, and school development. He is board member of the Swedish Participatory Action Research Society (SPARC) and the Swedish Interactive Research Association (SIRA), as well as expert advisor to the EU SWAFS Horizon 2020 research committee.

\section{References}

Adelman, C. 1993. Kurt Lewin and the Origins of Action Research. Educational Action Research, 1(1): 7-24. https://doi.org/10.1080/0965079930010102

Chesbrough, H. W. 2003. Open Innovation: The New Imperative for Creating and Profiting from Technology. Boston, MA: Harvard Business Press.

Fals-Borda, O., \& Rahman, M. A. 1991. Action and Knowledge: Breaking the Monopoly with Participatory Action-Research. New York: Apex Press.

Freire, P. 1985. The Politics of Education: Culture, Power, and Liberation. Westport, CT: Greenwood Publishing Group.

Johansson, A. W., \& Lindhult, E. 2008. Emancipation or Workability? Critical versus Pragmatic Scientific Orientation in Action Research. Action Research, 6(1): 95-115. https://doi.org/10.1177/1476750307083713

Kaplan, R. S. 1998. Innovation Action Research: Creating New Management Theory and Practice. Journal of Management Accounting Research, 10: 89-118.

Kemmis, S., McTaggart, R., \& Nixon, R. 2015. Critical Theory and Critical Participatory Action Research. In H. Bradbury (Ed.), The SAGE Handbook of Action Research (3rd ed.): 453-464. Los Angeles: SAGE.

Lewin, K. 1946. Action Research and Minority Problems. Journal of Social Issues, 2(4): 34-46. https://doi.org/10.1111/j.1540-4560.1946.tb02295.x

Reason, P., \& Bradbury, H. 2008. Handbook of Action Research: Participative Inquiry and Practice. Thousand Oaks, CA: SAGE.

Citation: McPhee, C., Hoppe, M., \& Lindhult, E. 2019. Editorial: Action Research. Technology Innovation Management Review, 9(4): 3-6.

http://doi.org/10.22215/timreview/1228

Keywords: action research, participatory research, participative, innovation 


\section{TIm Technology Innovation Management Review}

\section{Academic Affiliations and Funding Acknowledgements}
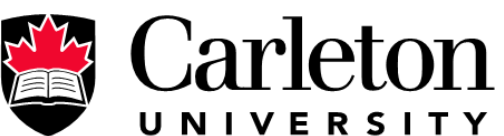

U N I V E R S I T Y

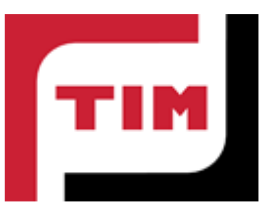

Technology Innovation Management (TIM; timprogram.ca) is an international master's level program at Carleton University in Ottawa, Canada. It leads to a Master of Applied Science (M.A.Sc.) degree, a Master of Engineering (M.Eng.) degree, or a Master of Entrepreneurship (M.Ent.) degree. The objective of this program is to train aspiring entrepreneurs on creating wealth at the early stages of company or opportunity lifecycles.

- The TIM Review is published in association with and receives partial funding from the TIM program. 